\title{
PELAKSANAAN BAI AL-ISTISHNA' TERHADAP PEMESANAN TERALIS PADA BENGKEL LAS DIKECAMATAN SIAK HULU MENURUT PERSPEKTIF ISLAM
}

\author{
Zainur $^{1}$, Marliyah ${ }^{2}$ \\ ${ }^{*} 1 \& 2$ Universitas Islam Negeri Sumatera Utara \\ Email: zainurpku@gmail.com
}

\begin{abstract}
Abstrak: Bai' al-istishna' menjual barang atau jasa dalam bentuk pemesanan dengan kriteria dan kondisi tertentu yang disepakati antara pembeli dan penjual dengan pembayaran yang dilakukan di muka, dengan angsuran, atau ditangguhkan. Bai' al-istishna pelaksanaan pemesanan di toko las di kecamatan teralis Siak Hulu menurut perspektif ekonomi Islam, ada beberapa masalah pada kenyataan yang telah berjalan untuk ini ada beberapa hal yang tidak sesuai dengan kesepakatan atau harmoni bai' al-istishna itu sendiri yaitu: pesanan barang tidak sesuai dengan spesifikasi yang disepakati, penundaan penyelesaian pesanan, kurangnya catatan kesepakatan pemesanan barang, dan keterlambatan pembayaran oleh pembeli dan itu tidak sesuai dengan konsep bai 'al-istishna dalam ekonomi Islam.
\end{abstract}

Kata kunci: Bai'al-istishna', Ekonomi Islam. 
PENDAHULUAN

Kegiatan jual beli sangat dibutuhkan oleh masyarakat sebagai sarana dan prasarana memenuhi kebutuhan sehari-hari. Dengan adanya jual beli maka akan timbul rasa saling membantu terutama di bidang ekonomi, sehingga hidup manusia berdiri dengan lurus, mekanisme hidup berjalan dengan baik. Pada hakikatnya Islam sudah mengatur cara-cara jual beli dengan sebaik mungkin, supaya jangan terjadi hal-hal yang tidak diinginkan atau menyimpang dari syarat jual beli itu sendiri.

Dalam kehidupan sehari-hari semakin meningkatnya ilmu teknologi menyebabkan semakin berkembang pula pola pemikiran manusia. Oleh karena itu, manusia juga memerlukan keamanan dan kenyamanan yang dianggap sangat penting.

Salah satu transaksi jual beli dalam keseharian adalah transaksi bai' al-Istishna. Bai' al-istishna' merupakan kontrak penjualan antara pembeli dan pembuat barang. Dalam hal ini, pembuat barang menerima pesanan dari pembeli. Pembuat barang lalu berusaha membuat barang pesanan yang dipesan si pembeli berdasarkan spesifikasi yang telah disepakati. Kedua belah pihak bersepakat atas harga serta sistem pembayaran, apakah pembayaran dilakukan dimuka, melalui cicilan atau ditangguhkan sampai suatu waktu pada masa yang akan datang (Antonio, 2021:113).

Pada saat sekarang ini usaha bengkel las teralis sangat menjanjikan untuk menopang perekonomian keluarga. Karena semakin meningkatnya penduduk dan pastinya ingin mendapatkan hunian yang layak serta keamanan dan kenyamanan. Terdapatnya usaha swasta yang bergerak di bidang teralis seperti teralis pintu,teralis jendela, teralis pagar, canopy, dan lainnya. Pelaksanaan bengkel las ini berada Di Kecamatan Siak Hulu Pekanbaru Riau dengan menerapkan prinsip bai' al-istishna'.

Namun, saat pesanan selesai terpasang sering kali pembeli atau pemesan belum bisa melunasi pembayaran dengan berbagai alasan, seperti belum adanya uang saat barang pesanan sudah terpasang, pembeli atau pemesan lupa membayarnya, pembeli sedang berada diluar kota. Pembeli ada yang memberikan alasan lebih mendahulukan membayar barang yang lain di toko usaha yang lain, dan ada pembeli yang mengulur-ulurkan waktu pembayaran dengan seringnya berjanji untuk membayar, dengan alasan belum sempat mengambil uang di bank. Pemesan atau pembeli sering memotong harga karena keterlambatan pemasangan barang tanpa adanya kesepakatan dan juga pemesan sering meminta tambahan pesanan setelah pemasangan tetapi tanpa tambahan pembayaran seperti yang disepakati pada awal transaksi, dan tidak adanya bukti pembayaran oleh penjual.

Di lain pihak si pemesan juga sering mendapatkan barang pesanannya tidak sesuai dengan spesifikasi dan kualitas yang diminta. Contohnya saja permintaan teralis jendela bentuk bunga tetapi yang terpasang teralis yang biasa tanpa bunga (Sapril (konsumen), Komunikasi Pribadi, 8 Juni 2021).

Bahan yang digunakan sering tidak sesuai dengan yang diinginkan dan kurangnya kerapian dalam pembuatan barang pesanan. Waktu penyeleaian barang pesanan selalu terlambat atau lama dan diluar perjanjian atau kesepakatan diawal dan tidak adanya perjanjian yang jelas antara pemesan dan pemilik bengkel (Rita (konsumen), Komunikasi Pribadi, 8 Juni 2021).

Beberapa bentuk kesalahan yang terjadi pada pelaksanaan pemesanan bai' al-istishna' yang dikemukan di atas, ada yang terdapat dari pembeli atau pemesan

SYARIKAT : Jurnal Rumpun Ekonomi Syariah Volume 4, Nomor 1, Juni 2021 
seperti keterlambatan pembayaran dengan berbagai alasan yang dikemukakan. Demikian juga dari penjual terjadinya ketidaksesuaian barang pesanan dengan spesifikasi yang diinginkan pembeli, tidak adanya catatan perjanjian. Ini menimbulkan pertanyaan apakah kondisi tersebut dibolehkan dalam Islam dengan beragam alasan yang dikemukakan, mengingat Islam sangat menginginkan kesesuaian dalam perjanjian.

\section{TINJAUAN PUSTAKA}

\section{Ba'I Al-Istishna}

Bai' al-istishna' merupakan kontrak penjualan antara pembeli dan pembuat barang. Dalam hal ini, pembuat barang menerima pesanan dari pembeli. Pembuat barang lalu berusaha membuat barang pesanan yang dipesan si pembeli berdasarkan spesifikasi yang telah disepakati. Kedua belah pihak bersepakat atas harga serta sistem pembayaran, apakah pembayaran dilakukan dimuka, melalui cicilan atau ditangguhkan sampai suatu waktu pada masa yang akan datang (Antonio, 2001:113).

Penerapan prinsip bai' al-istishna' pada bengkel las teralis ini tercakup dalam Al-Qur'an Surah Al-Baqarah ayat 282 yang berbunyi:

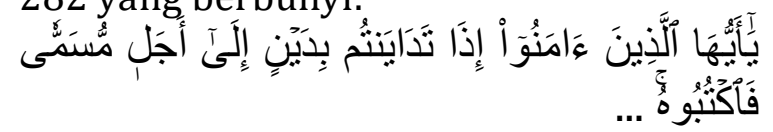

Artinya: "Hai orang-orang yang beriman, apabila kamu bermu'amalah tidak secara tunai untuk waktu yang ditentukan, hendaklah kamu menuliskannya...".

Menurut hukum Islam, untuk sahnya suatu perjanjian, di samping didasarkan atas kesepakatan antara kedua belah pihak, juga objek perjanjian itu harus memenuhi syarat-syarat tertentu. Antara lain sebagai berikut:
1. Merupakan benda bernilai yang mempunyai persamaan dan penggunaannya mengakibatkan musnahnya benda hutang,

2. Dapat dimiliki,

3. Dapat diserahkan kepada pihak yang berhutang,

4. Telah ada pada waktu perjanjian dilakukan (Jafri, 2000:122).

Dalam melakukan kontrak bai' alistishna' pembatalan boleh dilakukan selama tidak merugikan kedua belah pihak.Yang menjadi kelebihan dari pelaksanaan bai' al-istishna' ini adalah dapat memudahkan pembeli atau konsumen dalam pembayarannya karena dapat diangsur atau ditangguhkan.

\section{HASIL DAN PEMBAHASAN \\ Pelaksanaan Bai' Al-Istishna' Bengkel Las di Kecamatan Siak Hulu}

Jual beli pesanan (bai' al-istishna') merupakan kontrak penjualan antara pembeli dan pembuat barang seperti yang terjadi pada bengkel las di Kecamatan Siak Hulu dalam pemesanan teralis dalam kontrak ini pembuat barang menerima pesanan dari pembeli, pembuat barang lalu berusaha membuat barang pesanan menutut spesifikasi yang telah disepakati. Kedua belah pihak bersepakat atas harga serta sistem pembayaran.Apakah pembayaran dilakukan dimuka, cicilan, atau pada tempo yang sudah di tentukan.

Adapun pelaksanaan pemesanan teralis pada bengkel las di Kecamatan Siak Hulu yaitu pembuat barang menerima pesanan teralis dari pembeli pada bengkel las dengan mendatangi secara langsung bengkel las yang ada di Kecamatan Siak Hulu, pemesan yang sudah sering memesan atau berlangganan bisa melakukan pemesanan melelui via telepon. Pemesan memberikan spesifikasi barang yang diinginkan seperti bentuk atau motif yang diinginkan, bahan yang digunakan, 
ukuran, warna cat serta kesepakatan harga dan waktu penyelesaian pembuatannya. Dalam transaksi bai' alistishna' pada bengkel las di Kecamatan Siak Hulu barang yang bisa di pesan seperti teralis pintu, teralis jendela, pagar, canopy,garasi dan lain-lain. Bahan baku yang digunakan pada pembuatan teralis bermacam-macam tergantung pada jenis pesanan, contohnya dalam pemesanan pintu yang bermotif bunga bahan yang diperlukan seperti besi siku, besi petak, nako, dan jenis-jenis bunga.

Setelah pemesan memberikan spesifikasi dari pesanannya, kemudian Untuk ukuran dari barang pesanan, penjual langsung menuju lokasi tempat pemasangan untuk mengukur panjang lebarnya ukuran yang akan dibuat. Kemudian pemesan juga menetapkan tentang jenis cat dan warna cat untuk pesanan sesuai dengan keinginan pemesan (Siregar (Produsen), Komunikasi Pribadi, 10 Juni 2021).

Pemesanan teralis pada bengkel las di Kecamatan Siak Hulu ini penetapan harga biasanya didasarkan pada motif dan besar kecilnya ukuran, serta kualitas bahan yang digunakan untuk pesanan. Adapun contoh motif pada pemesanan teralis, seperti teralis motif antik, teralis motif bunga, dan bermotif minimalis dan lain-lain. Harga yang paling mahal biasanya bermotif antik dikarenakan pembuatan dari pada motif antik jauh lebih sulit dibandingkan dengan yang lainnya, sehingga dibutuhkan waktu yang lama untuk menyelesaikannya.

Pembayaran Pemesanan teralis pada bengkel las di kecamatan siak hulu ini dilakukan diawal sebagai uang muka untuk tanda jadi dari pemesanan dan pelunasan setelah pesanan atau barang yang pesan siap terpasang dikediaman pemesan.Ada juga pembeli atau pemesan yang melakukan pembayaran setelah pemasangan selesai terpasang di kediaman pemesan hal ini disesuaikan dengan kesepakatan antara kedua belah pihak.

Dalam pelaksanaan bai" alistishna" pada bengkel las di kecamatan siak hulu telah ditetapkan kapan pembayaran dilakukan, sebagaimana dengan kesepakatan yang telah dilakukan pada awal transaksi (saat akad terjadi). Begitu juga mengenai Waktu penyelesaian pesananan juga disepakati antara kedua belah pihak diawal transaksi (Jusman (Produsen), Komunikasi Pribadi 10 Juni 2021).

Apabila terjadi perubahan kriteria pesanan dari pihak pembeli atau pemesan, maka pembeli atau pemesan harus segera dilaporkan ke pembuat pesanan. perubahan bisa dilakukan apabila pembuatan barang yang dipesan belum selesai terbuat atau masih pada dasar sehingga bisa di ubah sesuai keinginan. Tetapi jika perubahan kriteria pesanan dan setelah akad, maka seluruh biaya tambahan ditanggung oleh pemesan (Samsul (Konsumen), Komunikasi Pribadi, 10 Juni 2021).

Bagi pembeli yang melakukan pemesanan pada bengkel las di Kecamatan Siak Hulu ini, pembeli atau pemesan harus memberikan beberapa keterangan kepada pembuat barang sebagai identitas pemesan, dan spesifikasi barang pesanan seperti:

a. Nama pemesan

b. No Hp/telepon pemesan yang bisa di hubungi.

c. Memberikan identitas yang jelas

d. Tempat pemasangan barang yang dipesan.

Dari pemesanan yang dilakukan pembeli, penjual mulai membuat pesanan sesuai dengan spesifikasi yang diberikan pembeli. Adapun tahap-tahap dalam pembuatan teralis sebagai berikut:

1. Tahap awal, yaitu pekerja mulai menyiapkan bahan baku seperti, besi petak, besi nako dan lain-lain (sesuai yang diperlukan), memotong sesuai

SYARIKAT : Jurnal Rumpun Ekonomi Syariah Volume 4, Nomor 1, Juni 2021 
ukuran yang diperlukan dan mulai membingkai dan mengelas bentuk awal sebagai dasar dari pembuatan teralis sesuai dengan bentuk pesanan pembeli dan kemudian memberikan motif sesuai pesanan.

2. Kemudian, tahap finishing, setelah pembingkaian telah sempurna pekerja mulai mengrinda dan mendempul pada bingkaian yang telah sempurna.

3. Tahap akhir, pengecatan barang pesanan dengan warna berdasarkan keinginan pemesan. Setelah selesai barang pesanan telah siap untuk dipasang dikediaman pemesan (Pendi (Produsen), Komunikasi Pribadi, 12 Juni 2021).
Untuk mendirikan bengkel las di Kecamatan Siak Hulu, pemilk bengkel harus mempunyai modal sekitar lebih kurang 20 juta, selain modal untuk mendirikan usaha ini juga harus memiliki skil atau keahlian dalam mengelas sebagai dasar dari pembuatan teralis. Adapun peralatan pokok yang harus dimiliki dalam membuka usaha ini seperti travo las, grinda duduk, grinda tangan, bor tangan, bor duduk, kompresor, dan lain-lain (Sami (Produsen), Komunikasi Pribadi, 17 Juni 2021).

Pada usaha bengkel las ini terdapat macam -macam model pesanan barang yang bisa di pesan dalam transaksi bai" al-istishna" seperti:

Tabel 1. Jenis Barang Pesanan Bai' Al-Istishna'

\begin{tabular}{|c|l|}
\hline No & \multicolumn{1}{|c|}{ Jenis Pesanan Teralis } \\
\hline 1 & Pintu rumah \\
\hline 2 & Pintu garasi \\
\hline 3 & Jendela \\
\hline 4 & Pagar \\
\hline 5 & Canopy \\
\hline 6 & Tower \\
\hline 7 & Kerangkeng AC,kerangkeng mesin air, tutup parit, jemuran \\
\hline
\end{tabular}

Sumber:Marjan (Produsen), Komunikasi Pribadi, 17 Juni 2021. 
Adapun tanggapan responden mengenai keterlambatan pembayaran dalam pemesanan teralis dari 60 orang responden yang menyatakan pernah dengan persentase $25 \%$ dikarenakan responden pernah melakukan keterlambatan pembayaran dalam pemesanan teralis (Opi (Konsumen), Komunikasi Pribadi, 28 April 2021). Dan yang menyatakan tidak pernah dengan persentase $31.66 \%$ dikarenakan responden tidak pernah melakukan keterlambatan pembayaran, ketika pesanan selesai responden langsung membayar lunas pembayarannya. Sedangkan yang menyatakan kadangkadang dengan persentase sebanyak 43.33\% dikarenakan responden kadang bisa membayar setelah pesanan selesai, kadang juga belum bisa melunasi pembayaran jika belum adanya uang saat pesanan siap terpasang.

Tanggapan responden mengenai akad perjanjian antara pembeli dan penjual dari jumlah produsen 43 orang, yang mengatakan lisan dengan persentase $83.33 \%$, produsen menyatakan secara lisan dikarenakan pembeli yang memesan teralis merupakan konsumen yang sudah berlangganan sehingga tidak memerlukan akad perjanjian melainkan rasa kepercayaan(Uir (Produsen), Komunikasi Pribadi, 30 April 2021). Serta yang menyatakan menggunakan tulisan dengan persentase $16.67 \%$. Dikarenakan pembeli hanya menginginkan nota harga barang yang dipesan tanpa menyinggung tentang akad atau perjanjian antara produsen dan konsumen yang ditanda tangani oleh kedua belah pihak, untuk memperkuat jika suatu hari ada complaint konsumen.

Tanggapan produsen terhadap keterlambatan pembayaran oleh pemesan dari 30 produsen, yang menyatakan sering dengan persentase 40\%, dikarenakan pemesan sering belum melunasi pembayaran setelah pesanan selesai terpasang, dengan berbagai alasan, seperti belum adanya uang, belum gajian, dan lain-lain (Ari (Produsen), Komunikasi Pribadi, 18 April 2021). Dan yang menyatakan tidak pernah dengan persentase 13.33\%, dikarenakan produsen tidak pernah mendapatkan pemesan yang tidak membayar melakukan pelunasan pembayaran setelah pesanan terselesaikan. Sedangkan yang menyatakan kadang-kadang dengan persentase 46.67\%, dikarenakan konsumen kadang-kadang tidak bisa melakukan pembayaran setelah pesanan terselesaikan.

Tanggapan produsen mengenai keterlambatan penyelesaian pesanan dari pemesan dari 30 orang produsen yang menyatakan sering dengan persentase sebanyak $13.33 \%$ dikarenakankan tempat usaha dan lokasi pemesan sangat jauh dan tidak adanya kendaraan untuk mengantar, sehingga keterlambatansering terjadi. Dan yang menyatakan tidak pernah dengan persentase 20\%,dikarenakan produsen selalu menyelesaikan pesanan tepat pada waktunya. Selanjutnya yang menyatakan kadang-kadang dengan persentase $66.67 \%$ dikarenakan kadang-kadang keterlambatan terjadi karena berbagai sebab salah satunya dikarenakan kurangnya bahan baku yang diperlukan, banyaknya pesanan dari konsumen, faktor cuaca seperti hujan dan mati lampu juga menyebabkan keterlambatan penyelesaian pesanan dari konsumen (Upik (Produsen), Komunikasi Pribadi, 30 April 2021).

\section{Ekonomi Islam Terhadap Pelaksanaan Bai' Al-Istishna' di Kecamatan Siak Hulu}

Dari pelaksanaan bai' al-istishna' secara pesanan yang dilakukan oleh 
pembeli dan pembuat barang di Kecamatan Siak Hulu, dan dari beberapa sumber rujukan hukum yang menjadi landasan dibolehkan transaksi bai' alistishna', maka dalam hal spesifikasi barang yang dipesan para pemesan atau pembeli sacara pesanan di Kecamatan Siak Hulu sudah sesuai dengan konsep bai' alistishna' dalam konsep ekonomi Islam. Karena kedua belah pihak sudah sepakat tentang spesifikasi teralis yang dipesan, di antaranya jenis barang, bentuk atau motif yang diinginkan, bahan yang digunakan, ukuran, warna cat serta kesepakatan harga dan waktu penyelesaian pembuatannya. Hal ini menurut penulis sudah sesuai dengan syarat dan ketentuan dari bai' al-istishna' bahwa spesifikasi barang harus jelas. Dan sesuai dengan hadits Nabi yang diriwayatkan oleh Imam Muslim:

Dari Hakim bin Hizam, dari Nabi Saw, beliau bersabda," Penjual dan pembeli mempunyai hak untuk memilih (khiyar) selama keduanya belum berpisah. Apabila mereka, penjual dan pembeli tersebut, berlaku jujur dan mau menerangkan (barang yang diperjual belikan), niscaya mereka akan mendapat berkah dalam jual belinya. Sebaliknya, apabila mereka berbohong dan mentupnutupi (apa-apa yagn seharusnya diterangkan mengenai barang yang diperjual belikan), niscaya berkah dalam jual beli itu akan dihapus (hilang (HR. Muslim) (Al-Albani, 2007).

Mengenai jangka waktu yang ditetapkan antara pemesan dan pembuat barang di Kecamatan Siak Hulu, pada praktek yang terjadi biasanya spesifikasi barang dan harga disepakati oleh kedua belah pihak, maka pemesan menanyakan kepada pembuat barang untuk memastikan kapan penyelesaian atau pemasangan selesai.
Pihak pembuat barang biasanya menyatakan penyelesaian barang pesanan berdasarkan sedikit atau banyaknya pesanan yang di minta oleh pemesan, bila pesanan sedikit lebih kurang satu minggu sudah selesai, jika pesanan dalam jumlah banyak bisa dua atau tiga minggu, hal ini tergantung dari pesanan si pemesan (Adi (Produsen), Komunikasi Pribadi, 30 April 2021). Penentuan jangka waktu yang dilakukan pemesan teralis di Kecamatan Siak Hulu secara pesanan jika di hubungkan dengan prinsip bai' al- istishna' dalam ekonomi islam, menurut penulis sudah sesuai, karena jangka waktu yang mereka tetapkan berdasarkan sedikit atau banyaknya pesanan setelah berlakunya perjanjian dan kesepakatan, hal ini sudah sesuai dengan konsep istishna'. Menurut Hudawiyah, bahwa Imam Syafi'i dan beberapa Ulama Hanafi menyatakan bahwa Rasulullah Saw, tidak menetapkan periode, sebagai syarat sahnya alistishna' (Ascarya, 2009).

Perjanjian dan kesepakatan yang terjadi antara pihak pemesan dan pembuat barang, penulis telah mendapatkan keterangan dari pembuat barang mereka melakukan perjanjian dan kesepakatan atas spesifikasi barang pesanan, hanya dengan lisan saja, tanpa menuliskan hasil dari perjanjian dan kesepakatan tersebut. Sehingga tidak mempunyai kekuatan hukum, yang bisa dijadikan bukti untuk menetapkan suatu keputusan jika terjadi perselisihan, antara keduabelah pihak dikemudian hari, perjanjian dan kesepakatan yang tidak dicatat di nota atau surat perjanjian oleh pembuat barang dan pemesan. Menurut penulis belum sesuai dengan konsep dalam ekonomi islam. Karena hal ini belum sesuai dengan Al-Qur'an Surah AlBaqarah Ayat 282, yang berbunyi: 


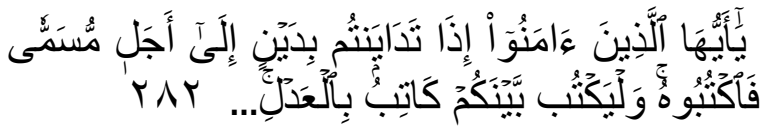

Artinya: "Hai orang-orang yang beriman, apabila kamu bermu'amalah tidak secara tunai untuk waktu yang ditentukan, hendaklah kamu menuliskannya. Dan hendaklah seorang penulis di antara kamu menuliskannya dengan benar".

Imam Syafi'i berkata: saya sendiri lebih menyukai adanya penulis dan kesaksian, karena hal itu merupakan petunjuk dari Allah $S w t$, yang demikian itu disebabkan bahwa jika kedua belah pihak dapat dipercaya maka terkadang salah atau keduanya meninggal dunia, sehingga tidak dapat diketahui lagi hak penjual atas pembeli, lalu hitunglah hak pembeli atau ahli waris atas barang tersebut (Muhammad, 2007).

Hal ini pembeli juga bertanggung jawab atas urusan yang tidak dapat dikembalikannya.Dan terkadang pikiran pembeli itu dapat berubah sehingga tanggung jawab kembali kepada penjual. Pembeli juga dapat berbuat salah atau keliru, tetapi ia tidak mau mengakui kesalahannya jika demikian maka ia termasuk orang yang suka berbuat dzalim karena tidak mau menyadarinya. Penjual juga dapat berbuat salah, lalu mereka mengakui apa yang bukan menjadi hak miliknya, dalam kasus seperti ini, maka penulisan dan kehadiran saksi dapat menjadi penghapus kekeliruan bagi pelaku jual beli dan ahli waris keduanya, sehingga ia tidak termasuk orang-orang yang berbuat dzalim kepada Allah dan yang lainnya (Albani, 2007). Hal ini juga dijelaskan dalam beberapa ayat dalam AlQur'an yaitu:

a. Al-Qur'an Surah An-Nahl 90. Artinya: "Sesungguhnya Allah menyuruh (kamu) berlaku adil dan perbuat kebajikan....."(Q.S AnNahl:90),

b. Al-Qur'an Surah Al-Maidah ayat 8 yang artinya: Hai orang-orang yang beriman hendaklah kamu jadi orangorang yang selalu menegakkan (kebenaran) Karena Allah, menjadi saksi dengan adil. Dan janganlah sekali-kali kebencianmu terhadap sesuatu kaum, mendorong kamu untuk berlaku tidak adil.Berlaku adillah, Karena adil itu lebih dekat kepada takwa.dan bertakwalah kepada Allah, Sesungguhnya Allah Maha mengetahui apa yang kamu kerjakan (Q.S. Al-Maidah:8).

Barang yang tidak sesuai dengan spesifikasi yang sudah di sepakati akan di ganti dengan barang yang sesuai dengan kesepakatan awal, ketidaksesuaian barang yang datang dengan barang yang dipesan, dalam hal ini hukumnya batal, karena salah satu syarat dalam rukun jual beli dari perjanjian tidak ditepati penjual atau pembuat barang, hal ini juga belum sesuai dengan konsep al-istishna' yang ada di dalam ekonomi islam dan tidak terpenuhinya syarat sah bagi jual beli istishna', sebagaimana hadits Nabi Muhammad Saw yang diriwayatkan oleh Imam Muslim "Disebutkan bahwa A'dda" bin Khalid berkata,"Nabi Saw. Menuliskan untuk-ku, ini yang dibeli Muhammad Saw. Dari Adda" bin Khalid; jual beli antara muslim dengan muslim, tidak ada cacat di dalamnya, bukan benda haram dan tanpa kejahatan."(H.R. Bukhari) (Albani, 2007).

Mengenai penundaan pembayaran oleh pembeli ketika pesanan yang terjadi di bengkel las Kecamatan Siak Hulu terhadap pemesanan teralis secara pesanan, pembeli belum bisa melunasi pembayaran ketika pesanan yang dipesan sudah selesai terpasang dikediaman pemesan.Pembeli belum bisa melunasi pembayaran dengan berbagai alasan yang 
dikemukakan. Bila yang berhutang tidak mampu membayar hutangnya pada masa jatuh tempo, maka orang yang menghutangi diharapkan bersabar sampai yang berhutang mempunyai kemampuan.

Menurut pandangan ekonomi islam mengenai hal demikian seperti yang dijelaskan pada Al Qur'an dan hadits Nabi Rasulullah Saw. Adapun firman Allah Swt dalam surah Al-Baqarah 280 yang berbunyi:

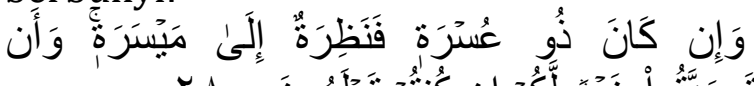

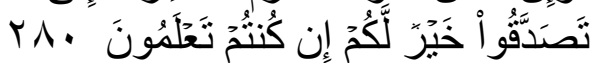

Artinya: "Dan jika (orang yang berhutang itu) dalam kesukaran, Maka berilah tangguh sampai dia berkelapangan. dan menyedekahkan (sebagian atau semua utang) itu, lebih baik bagimu, jika kamu Mengetahui".

Namun pada dasarnya pembayaran harus dilakukan pada waktu yang sudah ditentukan, bila yang berhutang mampu membayarnya. Tetapi menangguhkan pembayaran maka dia dinyatakan sebagai orang yang dzalim sebagaimana yang terdapat pada hadits Nabi berikut:

"Dari Abu Hurairah Ra, bahwa Rasulullah Saw bersabda,"penundaaan pembayaran utang oleh orang kaya merupakan perbuatan zalim (terhadap yang berpiutang), dan apabila salah seorang darimu diikutkan (dipindahkan utangnya) kepada orang kaya, maka hendaklah ia menerimanya (HR. Muslim)(Albani, 2007).

Muamalah pergaulan hidup tempat setiap orang melakukan perbuatan dalamhubungannya dengan orang lain yang menimbulkan hubungan hak dan kewajiban,merupakan bagian terbesar dalam aspek kehidupan manusia. Oleh karenanya, Islam menempatkan bidang muamalah sedemikian penting, hingga
Berangkat dari hal itu semua, Islam bersikap lebih longgar dalam masalah hukum pada muamalah. Hukum Islam memberikan ketentuan bahwa pada dasarnya hukum dalam muamalah adalah mubah, hingga ada dalil atau nash yang mengharamkannya (Az-Zuhaily, 1997).

\section{SIMPULAN}

Berdasarkan uraian di atas maka dapat disimpulkan bahwa pelaksanaan bai' al-istishna' terhadap pemesanan teralis pada bengkel las diKecamatan Siak Hulu terdapat beberapa permasalahan pada realitanya yang berjalan selama ini yang tidak sesuai dengan konsep ekonomi Islam, baik akad maupun rukun bai' alistishna' itu sendiri. Seperti pesanan barang yang tidak sesuai dengan spesifikasi yang disepakati antara pembeli atau pemesan kepada penjual atau pembuat pesanan, seringnya terjadi keterlambatan penyelesaian pesanan oleh penjual, dan tidak adanya catatan perjanjian yang dituliskan antara penjual dan pembeli, dan penundaan pembayaran yang dilakukan pembeli pada saat pesanan sudah terselesaikan dengan berbaagai alasan yang dikemukakan pembeli.

Menurut pandangan ekonomi Islam barang pesanan yang tidak sesuai spesifikasi yang telah disepakati hukumnya batal dikarenakan tidak terpenuhinya rukun dan syarat bai' alistishna'. Keterlambatan penyelesaian pesanan hukumnya masih bisa di maafkan, tidak adanya catatan perjanjian belum sesuai dengan konsep ekonomi islam, dan penundaan pembayaran oleh pembeli atau pemesan hukumnya masih bisa di maafkan tergantung dari alasan yang dikemukakan pembeli. 


\section{DAFTAR RUJUKAN}

Al-Albani, M. Nashiruddin. (2007). Ringkasan Shahih Bukhari II. Jakarta: Gema InsaniPress.

Antonio, Muhammad Syafi'i. (2007). Bank Syari"ah dari Teori ke Praktik, Jakarta: Gema Insani.

Ascarya. (2009). Akad \& Produk Bank Syari"ah. Jakarta: PT. RajaGrafindo Persada.

Az-Zuhaily, Wahbah. (1997). Al-Fiqhu AlIslami Wa Adillatuhu, Damaskus: Darul-Fikr.

Departemen Agama RI. (2007). Al-Qur"an dan Terjemahannya,Bandung: Diponegoro.

Jafri, Syafii. (2008). Fiqh Muamalah, Pekanbaru: Suska Press.

Muhammad, Imam Syafi'i Abdullah Bin Idris, 2007, Ringkasan kitab Al Umm, Buku 2 Jilid3-6, Jakarta: Pustaka Azzam. 